\title{
SEYYEDHOSSEIN NASR ON ISLAM AND SCIENCE
}

\author{
Rif'at Husnul Ma'afi ${ }^{1}$, Muhammad Fiqih Cholidi ${ }^{2}$ \\ Universitas Darussalam (UNIDA) Gontor ${ }^{1,2}$ \\ rifathaem@gmail.com ${ }^{1}$, fiqihmuhammad26@gmail.com ${ }^{2}$
}

\begin{abstract}
Science and religion are two variables that are warmly discussed by contemporary scientists. John F. Haught for example explains the relationship between religion and science through four phases, namely, conflict, contrast, contact, and confirmation. Between these four phases, John F. Haught himself was in a confirmation position. Likewise Seyyed Hossein Nasr, a Muslim scientist and philosopher, is in the same position as John. This is known from his scientific concept known as Scientia Sacra. This concept is unique from the concept of confirmation or integration of science with religion, especially Islam. Although in the Islamic body there is no conflict between the two, new conflicts arise between the two relations caused by the characteristics of modern science which cause many multidimensional crises. This is what triggers the attitude of Muslims who are indifferent to science. In relation to Islam and science, Nasr has its own model in integrating the two. The model itself departs from the doctrine of cosmology which he considers to be a medicine from the paradigm of modern science: narrow, dark, and divided. The model in integrating science and Islam is to change the paradigm of modern science into the paradigm of Scientia Sacra who sees science as it should. So, science cannot be separated from Islam and must follow the principles in Islam.
\end{abstract}

Keywords: Scientia sacra, integration, absolute reality, multidimensional crisis

\section{INTRODUCTION}

The secret of scientific movement's growth and progress has been accomplished by Muslim in the middle ages, based on the teachings of Islam and the noble principle, which is reflected in Al-Quran. From the beginning of Islam's coming, Muslim scientists are very considered about Al-Quran's miracle and try to affirm the unity of science and religion purpose. Most of them had achieved the popularity in this field, like Al-Kindi, Al-Bairuni, AlQazwaini, and so on. In fact, there are branches of science -for example, astronomy- start to notice and deepen it cause of it relation directly toward religious matter which should be known by a Muslim, like prayer 
Rif'at Husnul Ma'afi \& Muhammad Fiqih Cholidi | SeyyedHossein Nasr...

times, the position of Holy Land, and coming a time of Ramadhan'shilal. ${ }^{1}$

Concerning science's relation toward religious matter, we must have heard of the development of this relation in the West history. Actually, if we notice to the West, the conflict between religion and science is the conflict in materialism and biblical literalism. The issues raised in the conflict revolved around the existence of God and opposing theories of science that contradict religious claims. John F. Haught, a Christian theologian, and physicist explained the typology of the relationship between religion and science in the West history as follows. ${ }^{2}$

First, is conflict. Many scientistsimagine that religion will never come to be reconciled with science. It was the main reason that religion apparently cannot demonstrate the truth of its ideas in a straightforward way, whereas science can. Religion tries to sneak by without providing any concrete evidence of God's existence. But,

\footnotetext{
${ }^{1}$ Prof. Dr. Ahmad FuadBasya, SumbanganKeilmuwan Islam PadaDunia, (Jakarta Timur: Al-Kautsar, 2004), p. 74

${ }^{2}$ John F. Haught, Science and Religion from Conflict to Conversation, (New York: Paulist Press, 1995), p. 9
}

science is willing to test all of its hypotheses and theories against experience. So, religion cannot do this in a way that is satisfying to an impartial witness, skeptics claim, so there must be a conflict between science and religion's understanding. ${ }^{3}$ Second, is contrast. Many scientist and theologians didn't find such opposition between religion and science. Religion should not be judged by the standards of science, nor vice versa because the questions of each asks are so completely disparate, and the content of their answers so distinct, that it makes no reason to compare them with each other. ${ }^{4}$ Third, is contact. The term "contact" implies coming together without necessarily fusing. Contact proposes that scientific knowledge can broaden the horizon of religious faith and that the perspective of religious faith can deepen our understanding of the universe. ${ }^{5}$ Fourth, is confirmation. It means that religion is in a very deep way supportive of the entire scientific enterprise.

\footnotetext{
${ }^{3}$ Ibid, p. 10

${ }^{4}$ Ibid, p. 13

${ }^{5}$ Ibid, p. 18
} 
Of the four typologies above, John F. Haught views more in the confirmation or integration between science and religion. As did John, a Muslim scholar, SeyyedHossein Nasr, has a main role in the integration of science and religion, especially in Islam. He is a scientist who is very critical of the modern world. ${ }^{6}$ His various criticism culminated in the idea of a paradigm shift in science and integrate it with Islam. In fact, Nasr asserts that the greatest mistake of modern science is its disengagement from the religion that he calls 'secular science'. Nasr uses the cosmological doctrines that paid much attention to the Quranic view of nature, not the speculative and demonstrative idea from philosophers. So that, there aren't many conflicts between science and Islam since its beginning.

But, a new conflict between Islam and science arises today in Muslim's mindset which ignores science development for Islamic intellectual cause of characteristic of modern science which arises

\footnotetext{
${ }^{6}$ Ach. Maimun,Seyyed Hossein Nasr, Pergulatan Sains dan Spiritualitas Menuju Paradigma Kosmologi Alternatif, (Yogyakarta: IRCiSoD, 2015), p. 8
}

multidimensional crisis and disengagement from the religion. So, the reconstruction is needed, especially science principal reconstruction which is raising some critiques and matters in the modern era.

Inthe researcher's opinion, SeyyedHossein Nasr is well-educated persons in science world with a west educational background. Other than as a scientist, he has deep mastery in Islamic science which called by Scientia sacra. It is found in his book 'Knowledge and The Sacred'. He said about his concept Scientia sacra:"Scientia Sacra is none other than sacred knowledge which lies at the heart of every revelation and is the center of that circle which encompasses and defines tradition."

Those things motivate the researcher to discussSeyyedHossein Nasr's model relating to Islam and science. So, the purpose of this research is to explain SeyyedHossein Nasr's model to integrate Islam and science. For this purpose, the researcher use qualitative study of literature (Library Research) and documentation method for collecting data with references to two sources, 
Rif'at Husnul Ma'afi \& Muhammad Fiqih Cholidi | SeyyedHossein Nasr...

primary source, and secondary source.

\section{Background of SeyyedHossein Nasr' Intellectual}

Nasr's formal education was undertaken in Teheran and Qum, matching to Persia curriculum. Nasr got the education in traditional sciences (philosophy, kalam, Sufism, and Fiqh) there. Moreover, Nasr studied Islamic and Persian sciences too in his house, so as the additional lessons, like France language. ${ }^{7}$

Nasr's childhood has given the important basic in his scholarly development. Abundant of the traditional teaching of Persia as well as very traditional religious family life has given him the strong initial understanding, especially to view the reality. The entire of his discussion with his father about various matters, react enough toward his personality. Then, the basic introduction was enhanced after his anxiety in Massachusetts Institute of Technology (MIT).

Since 12 years old, Nasr went to the USA for study. He got into completely different life from his life in Iran. Nasr studied in The Paddie

\footnotetext{
${ }^{7}$ Ach.Maimun, op.cit, p. 45
}

School, Highstown, New Jersey. For four years in this school, he got English education, science, American history, West culture, and Christianity. His studying graduated in 1950.

Then, Nasr became the student of Massachusetts Institute of Technology (MIT) and the first Iranian there. Nasr chose physics major, because of his will to gain knowledge about the nature of a thing, at least, at the level of physical reality. However, Nasr feels pressured by the scientific climate that imposes positivism empirically. Finally, the various metaphysical problems that he saw were not questioned or could not be adequately answered. His anxiety appeared by the serious doubts about the ability of physics and escorted him to the meaning of the nature of reality. ${ }^{8}$

Then, Nasr cured his anxiety by studying another study, by reading intensively another book and following various quick education in the humanities field. In this progress, he met Giorgio de Santillana - a philosopher and famous specialist of science's history from Italia - and

${ }^{8}$ Ibid, p. 46 
Jurnal Yaqzhan : Analisis Filsafat, Agama dan Kemanusiaan|

Vol 5, No 1, Juni 2019

studied seriously about ancient Greece's wise in Pythagoras philosophy, Plato's, Aristoteles', and Plotinus'. Moreover, Nasr studied medieval Europe's philosophy, Dante's mystic doctrine in his Divine Comedy, ${ }^{9}$ Hinduism, and criticism of modern western thought. ${ }^{10}$

Giorgio de Santillana presented to Nasr Rene Guneon works, the most important traditionalist figure. Guneon was the important icon in the formation of Nasr's traditional perspectives. He also had the chance to browsing Coomaraswamy library, so he can know more the thought of traditional philosopher in the world, like FrithjofSchuon, Titus Burckhardt, Marco Pallis, and Martian Lings. All of them have an important influence on Nasr's intellectual and spiritual. However the most influential were Schuon because most of Schuon's work became the

\footnotetext{
${ }^{9}$ Divine Comedy considered as one of greatest work of literature during medieval age. Divine Comedy explained about Dante's imaginative trip to Heaven and Hell by Virgilius' guidance, a Roman poet and Dante's best friend. Once, after witnessing the situation in Hell and Heaven, they finally arrived in Heaven. That's where Virglius handed Dante over to Beatrice and the two men reached the throne of God accompanied by an angel. But Dante could not see the face of God, because his view was dazzled by scintillating the Creator.

${ }^{10}$ Ibid
}

most important part in Nasr's later thought and spiritual life. ${ }^{11}$

After graduating from MIT in 1954, Nasr continued his education at Harvard University with geology and geophysical specialties until he won the M.Sc glass in $1956 .{ }^{12}$ Then, he continued his education at the doctoral level (Ph.D.) with the history of science specialties.

When studying in Harvard, Nasr got around Europe to broaden his horizons of thought and build various important relations. $\mathrm{He}$ visited some countries, especially France, Switzerland, England, Italy, and Spain. In his intellectual tours, Nasr met with Schuon and Burckhardt, thus further strengthening the orientation of his life. Moreover, Nasr visited Marocco and met famous spiritualist, he is Syaikh Ahmad al'Alawi. Nasr's life in Harvard witnessed the crystallization of most of his intellectual and spiritual side in worldview, the part that determines his discourses, academic careers, also his scholarship. ${ }^{13}$

At the age of 25, Nasr finished his doctoral education and earned his

\footnotetext{
${ }^{11}$ Ibid, p. 48

${ }^{12}$ Ibid

${ }^{13}$ Ibid, p. 49
} 
Rif'at Husnul Ma'afi \& Muhammad Fiqih Cholidi | SeyyedHossein Nasr...

Ph.D. (1958) with a dissertation entitled Conception of Nature in Islamic Thought and Methods Used for Its Study by the Ikhwan al-Safa, al-Biruni, and IbnSina. Then, the dissertation was published under the title Introduction to Islamic Cosmological Doctrines. ${ }^{14}$ Despite an offer to become an assistant professor at MIT, Nasr chose to return home.

Upon arrival in Iran, Nasr was offered the position as Professor of philosophy and history of science at the Faculty of Literature of Tehran University. At the age of 30, Nasr became the youngest professor at his university. Nasr used his position and influence to create profound changes and develop a philosophy program at his university that had been heavily influenced by French intellectuals.

From 1969-1972, Nasr served as dean of his faculty and vice rector in the academic field. In 1972, he was appointed by the Shah of Iran to Arymehr's leader and to develop it like MIT based on the roots of Iranian culture. In this case, Nasr initiated a study of the philosophy of science based on Islamic philosophy of science. In 1973, Nasr was appointed

\footnotetext{
${ }^{14}$ Ibid, p. 49
}

by the Queen of Iran to lead a center of philosophy development studies known as the Imperial Academy of Philosophy. ${ }^{15}$

\section{SeyyedHossein Nasr's Works}

His works begun when his dissertation was published. His first work is Science and Civilizationin Islam. ${ }^{16}$ Before, at the age of 20 years, he published An Introduction to Islamic Cosmological Doctrines, the edition of his dissertation revision. ${ }^{17}$ Moreover, Nasr also published Three Muslim Sages in Iran. This book was the textbook in courses of Islamic Philosophy and Science in Iran's Universities since three decades ago.

The other work of his is Ideals and Realities of Islam. This book contains everything about Islam that became widely read by the public. Along with this, so Nasr published his book entitled Islamic Studies. ${ }^{18}$ This book contains the collection of articles which discuss fundamental aspects of Islamic tradition. This book was developed further then published

\footnotetext{
${ }^{15}$ Ibid, p. 51

${ }^{16}$ Ibid, p. 50

${ }^{17}$ Nidhal Guessoum, Islam's Quantum Question Reconciling Muslim Tradition and Modern Science, (London: I.B. Tauris, 2011), p. 194

${ }^{18}$ Ibid, p. 53
} 
Jurnal Yaqzhan : Analisis Filsafat, Agama dan Kemanusiaan|

Vol 5, No 1, Juni 2019

with the title Islamic Life and Thought. ${ }^{19}$

When Nasr invited by Divinity School to deliver the Rockafeller lectures at the University of Chicago in some aspects about religion, philosophy, and the environmental crisis, he accepted the challenge gladly and wrote Man and Nature The Spiritual Crisis of Modern Man, which published 1966, two years after his lecture in Chicago. ${ }^{20}$ This book contains philosophical and spiritual roots of the question and his first prediction about the coming of the environmental crisis which was then called the ecological crisis. This book was translated into several European languages, including French, Italian, Spanish, Portuguese, and Bosnian. The Islamic world did not show much interest in it, except in Turkey. It's known by his translated book into Turkish. This work also put Nasr on the front line of the debate and discussion concerning the deeper philosophical and religious factor involved in the environmental crisis. ${ }^{21}$ Other works related more directly to

\footnotetext{
${ }^{19}$ Ibid.

${ }^{20}$ Lewis Edwin Hahn, The Philosophy of SeyyedHossein Nasr, (Chicago: Open Court Publishing Company, 2001), p. 36

${ }^{21}$ Ibid
}

philosophical matters which need to be mentioned separately. These works include Islam and The Plight of Modern Man which contains sections devoted to comparative philosophy and the future of the study of philosophy in the Islamic World, and Sufi Essays, which also become well known in its Italian, French and Spanish translation and which contains a number of chapters on the metaphysical dimensions of Sufism. ${ }^{22}$ By 1980, Nasr began to write again. He resumed his research and prepared his script to be delivered in Gifford's lecture, which is a very prestigious lecture in the University of Edinburgh. Nasr delivered the lecture in natural theology and philosophy of religion in the West. From this lecture, his book Knowledge and The Sacred was published as one of his important philosophical works. ${ }^{23}$

In 1994, Nasr was invited to deliver Cadbury lecture in University of Birmingham. Then, he wrote Religion and The Order of Nature which contains his material in this lecture. $^{24}$

\footnotetext{
${ }^{22}$ Ibid, p. 37

${ }^{23}$ Dr. Ach. Maimun, op.cit, p. 55

${ }^{24}$ Ibid, p. 57
} 
Rif'at Husnul Ma'afi \& Muhammad Fiqih Cholidi | SeyyedHossein Nasr...

In 1995, Nasr with Oliver Leaman, British scholars of Islamic and Jewish Philosophy, edited and published History of Islamic Philosophy (two volumes). This book includes the articles about Islamic philosophy which written by the world's leading scholars in it. ${ }^{25}$ Then, he finished four volumes of his great book An Anthology of Philosophy in Persia with his former student, Mehdi Aminrazavi. Besides being interested in philosophy, Nasr also showed his interest in the subject of science. It was shown by publishing next work entitled The Need for The Sacred Science. $^{26}$

\section{SeyyedHossein Nasr on Islam}

Religion in Islam, often expressed in Arabic, which is adDeen, which is derived from the adDayn, which means the debt. Thus, ad-din here means to repay our debt to God and involves the whole of our lives, because we owe to God not only to what is given to us individual but all the gifts in the form of existence itself. For the mind of a Muslim, it is a fact that the most obvious and conditions of the largest,

\footnotetext{
${ }^{25}$ nasrfoundation.org

${ }^{26}$ Dr. Ach. Maimun, op.cit, p. 58
}

which is when only ourselves to act, there is nothing and God are everything, what belongs to us is not from us, and all of it belongs to God. $^{27}$

In the perspective of Islam, the religion is not only seen as a part of life or certain activities, such as art, ideas, trade, social discourse, or politics. More than that, it is a matrix and outlook of life, including in the case where the whole activity, effort, creativity, human thought takes place.

Islam is not just a religion. In modern terms, which is defined by the secular world, that religious life occupies a small part of everyday life for most people. On the contrary, Islam is a religion as a total way of life. Islam never accepted the validity of areas outside the field of religion and holiness and refused to align any reality to dichotomize between the sacred and the profane or secular, or between spiritual and worldly.28 AlQuran, as the holy scripture, always pointing to the mundane, which is different from the eternal reality of the other world (al-dunya and alakhiroh). However, this dichotomy

\footnotetext{
${ }^{27}$ SeyyedHossein Nasr, Islam, (New York: HarperCollins e-books, 1995), p. 25

${ }^{28}$ Ibid, p. 26
} 
should not be confused by the division between the sacred or profane. On the one hand, could be mundane in the whole religious aspect, which worldliness itself has religious significance. However, the other could not become secular in this universe unless one claims freedom of religion and sacred things for certain areas of life. $^{29}$

\section{SeyyedHossein Nasr on Science}

Scientific terms, is actually only understood the extent of the use of the English language shall prevail. SeyyedHossein Nasr, himself, said that science is ever-changing knowledge of the physical world based on rationality and empiricism. Nasr then divides science itself into two parts, namely the Islamic sciences and modern science. This division is based on the foundation of the science respectively. Here's an outlook Nasr gives regarding both of the science division.

\section{Islamic Science}

Islamic Science in view of SeyyedHossein Nasr is a science developed by Muslims than two centuries into the future, which is one of the great achievements of Islamic

\footnotetext{
${ }^{29}$ Ibid, p. 27
}

civilization. ${ }^{30}$ Without it, there would not be medieval, renaissance, or Western science. In fact, there will not be the most important studies of nature that connect them with a religious nature, which has been achieved by the Islamic civilization. This expression was first introduced by Nasr when there were very few Muslims who are seriously interested in these topics.

Nasr considers Islamic science as traditional science. It is obvious because traditional Islamic science is science itself, which puts God, sacred things and people as the main things that need to be considered. ${ }^{31}$ From here, there was another term that is often called Scientia Sacra. Scientia Sacra itself is considered Nasr as traditional conception of knowledge of this science. He defines sacred knowledge as knowledge is located in the heart of every revelation and at the center of a circle that covers and characterize tradition. ${ }^{32}$ Scientia Sacra then regarded as sacred knowledge applications to various areas of reality which leads man towards spiritual

\footnotetext{
${ }^{30}$ SeyyedHossein Nasr, A Young Muslim's Guide to the Modern World, (Chicago: The Library of Islam, 2003), p. 85

${ }^{31}$ NidhalGuessoum, op. cit, p. 205

${ }^{32}$ Ibid, p. 206
} 
Rif'at Husnul Ma'afi \& Muhammad Fiqih Cholidi | SeyyedHossein Nasr...

perfection. Thus, by itself, a sacred science also includes the traditional sciences. $^{33}$

\section{Modern Science}

The difference between modern science and Islamic science seems to contrast. According to Nasr, Western science or modern science is based on the assumption that the natural world as a reality apart from God, or highest level of truth. In fact, we can find some profound differences between the views of Western science and Islamic science. ${ }^{34}$

Philosophically, the background of modern science itself is totally different from traditional science contained in medieval European science, Islamic science, even to the ancient Egyptian and Greek science, although science Modern is considered, based on the sciences. Modern science has emerged towards Scientist Revolution happened around eleven or seventeenth century, which at that time, European philosophy itself against revelation and religious views. It can be said that the foundation of modern science is a philosophical view of the special attention to the parameters of the

\footnotetext{
${ }^{33}$ Ibid.

${ }^{34}$ Ibid, p. 182
}

physical world, such as space, time, matter, motion, and energy into a reality that is free from a higher order of beings and separated from the power of God. ${ }^{35}$

In addition to separate science with ultimate reality, modern science was separating himself from the ethics that has become characteristic of modern science itself since the beginning of the emergence to date. This is clearly evident from the attitude of modern scientists who do not care about the impact of all inventions because they assume the role they only seek knowledge and is not responsible for what is produced. $^{36}$

\section{Integration Model between Islam and Science \\ Moving from Nasr criticism} against modern science, Nasr wanted to offer a solution to shift the paradigm that became the fulcrum of modern science to conform to Islamic traditions that had long been abandoned. Therefore, various solutions offered to resolve the resulting crises of modern science, then stick to the surface, and only

\footnotetext{
${ }^{35}$ Ibid, p. 183

${ }^{36}$ Ibid, p. 189
} 
touches areas that do not meet the principles. $^{37}$

The paradigm formulated by Nasr is approaching paradigm that has been formulated previously by Plato. Because according to Plato, the paradigm is the origin of Divine, namely as the basic form of the heavenly (celestial archetype) manifested, in reality, the historical life of mankind. ${ }^{38}$ Thus, the paradigm of science offered by Nasr is a traditional cosmology, namely the nature of philosophy that is rooted in the traditional teachings. Before discussing ideas of Nasr regarding metaphysical cosmology, the researcherhas to explain the context, the position, and significance of cosmology in the map of philosophy and science, so it must be the choice of the solution.

\section{Cosmology as Basic Science}

Cosmology is the branch that has a field operation on issues relating to natural or cosmic reality in general. In this case, the reality of cosmic or mundane reality referred to is the

\footnotetext{
${ }^{37}$ SeyyedHossein Nasr, Religion and The Order of Nature, (New York: Oxford University, 1996), p. 5

${ }^{38}$ SeyyedHossein Nasr, The Need for a Sacred Science, (Richmond: Curzon Press, 1994), p. 18
}

world so far as we experience a whole, which is not only limited to inanimate objects (physiochemical) but also all living things, as a material object cosmology. ${ }^{39}$ As a branch of philosophy that specifically discusses the nature, cosmology has an important role for science, also called natural sciences. The roles are divided into three, namely:

a) Collecting all the knowledge that is fragmented into a universal and integral unity of the whole of science, so that become a basic view of the cosmic reality.

b) To evaluate and critique or disclose the nature and formulate it systematically, thus forming a worldview that became a basic guide the development of science and its universal application. ${ }^{40}$

c) Remodel modern science madebarriers because frameworks and theories formulated keep maintaining intellectual independence, inclusion, and tolerance for knowledge and new findings.

The central role of the worldview of cosmic reality makes Nasr argues that science is at the root

\footnotetext{
${ }^{39}$ Ibid, p. 114

${ }^{40}$ Ibid
} 
Rif'at Husnul Ma'afi \& Muhammad Fiqih Cholidi | SeyyedHossein Nasr...

of the crisis because it rests on the paradigm that is lost, the worldview of nature (cosmology) which deviates from its original meaning. According to Nasr, cosmology is:

A science dealing with all orders of formal reality, of which the material is but one aspect. It is a sacred science which is bound to be connected to revelation and metaphysical doctrine in whose bosom alone it becomes meaningful and efficacious. $^{41}$

As a philosophical understanding of nature, traditional cosmology is a science in the sense of loose and aims to reveal the hierarchical structure of the universe and its divine origin, so that the symbolic meaning could be captured. $^{42}$

2. Traditional Science and Scientia Sacra as Cosmic Science

In essence, Scientiasacraare the science of metaphysics or as the real thing, especially to usher people to be able to distinguish the real thing (the real) and imaginary (illusory).Scientia

\footnotetext{
${ }^{41}$ SeyyedHossein Nasr, The Encounter of Man and Nature, the Spiritual Crisis of Modern Man,(London: Allen \&Unwin, 1968), p. 22

${ }^{42}$ Ach.Maimun, op. cit, p. 121
}

sacra are the core of traditional knowledge about the cosmos, while the more traditional disciplines as branches. ${ }^{43}$ Traditional science-based Scientia sacra that are used as an alternative when science that there is now rated dumped so that a secular science. $^{44}$

Science starts from the traditional hierarchical vision of cosmic reality which is positioned as the lowest level of physical reality. However, it has significance because it reflects a higher level through symbols. Some of the symbols are used as a gateway to enter the territory which is less captured. People who are able to read the symbols that will be able to capture the origin of Divine, as well as the ontological dependence of material reality to a higher order of reality. ${ }^{45}$

In Nasr's desired science, to know something is not to overpower. Therefore, sense of knowing is just for self-transcendence, ${ }^{46}$ so that

\footnotetext{
${ }^{43}$ SeyyedHossein Nasr, Knowledge and the Sacred, (New York: State University of New York Press, 1989), p. 132-133

${ }^{44}$ Ach.Maimun, op. cit, p. 146

${ }^{45}$ SeyyedHossein Nasr, The Role of The Traditional Sciences in The Encounter of Religion and Science, an Oriental Perspective.

${ }^{46}$ SeyyedHossein Nasr, Knowledge and the Sacred, p. 4
} 
wisdom could be obtained. In the end, all the potential that can be used to acquire knowledge (sensory, rational, and intellectual) should be used optimally. $^{47}$

3. Integration Model of Science and Islam by Nasr

There are many contemporary Muslim philosophers who have the concept of integration between Islam and science. Most of them, beginning their integration from transforming the object of knowledge (in other word science itself). Most of their focus are directing modern science to Islamic principles and eliminating the secular concept from modern science. But, Nasr has the different model from theirs. Nasr's integration model is to integrate between science and Islam appear to change the paradigm which resulted in a new phenomenon in the world of science. Then, Nasr has a major project under the auspices of the paradigm with the aim of replacing the paradigm of modern science that contains defects with a new paradigm. Basically, the new paradigm offered a refinement of the

\footnotetext{
${ }^{47}$ Ach.Maimun, op. cit, p. 150
}

fundamental flaws of modern science. $^{48}$

The weakness of modern science can be understood from three basic characters of science news stories become a model of integration offered Nasr, the vastness, unity, and light. ${ }^{49}$ Therefore, the third character rests on the weaknesses of modern science are visible from various claims. By doing so, it can be said that modern science has three characters.

First, Narrow nature. The existence due to the narrow nature of modern science just dwell on material reality and not expanding the horizons of the possibility of another truth.

Second, Fragmented character. The existence of a fragmented character due to modern science are not able to connect a variety of specialties and sub-special from diverse disciplines. In addition, the fragmented nature also getting rid of religion, philosophy, and art as a source of knowledge and truth of the other.

\footnotetext{
${ }^{48}$ Ibid, p. 153

${ }^{49}$ Robert M. Augros and George N. Stanciu, The New Story of Science: Mind and The Universe, (Chicago: Gateway Editions, 1984), p. 163
} 
Rif'at Husnul Ma'afi \& Muhammad Fiqih Cholidi | SeyyedHossein Nasr...

Third, Dark character. The existence of dark character is because modern sciences are not able to give a satisfactory explanation on several important issues, such as the beauty of the world of thoughts and dimension of cosmic reality. ${ }^{50}$

Of the three basic problems of modern science has been mentioned, as well as three models of integration offered, Nasr explains further how the integration of three models could provide a solution to the three basic problems of modern science.

a) Vastness

This is in accordance with the first issue of basic science, which has a narrow character. Modern science is considered to be narrow because it limits the object of scientific study as well as the process to obtain the truth. Narrowness is evident from the description of reality only by the material. Another reality comes as no principle or even could not be recognized as truth. Thus, the breadth becomes one of the essential characters of the new paradigm of science to sue the fundamental problems in modern science. One important problem that a lot of the

\footnotetext{
${ }^{50}$ Ach.Maimun, op. cit, p. 158
}

spotlight is materialism as a paradigm. $^{51}$

1) Lawsuit Against Materialism

SeyyedHossein Nasr expressed his criticism of modern science with a focus on materialism. For Nasr, one of the biggest mistakes of modern science is the notion of the material as the basis of reality and denying the reality of the other. Because, in fact, the material aspect is simply the reality of the periphery of the circle of existence as a whole.The average ultimate reality was behind the physical reality of the material. Material-physical reality only a reflection or manifestation of the ultimate reality behind it.That ultimate reality which must be found to determine the nature of reality and understanding reality as a whole. ${ }^{52}$

In the world of science, materialism - as a paradigm - can't talk much about the complex reality. The imposition of this paradigm will only give birth to confusion. In addition, it will result in reality simplification which is not that simple. Various reforms are happening in the world of science is evidence that materialism has

\footnotetext{
${ }^{51}$ Ibid, p. 159

${ }^{52}$ nasrfoundation.org
} 
limitations, narrowness, and weakness, so it should be enhanced with a wider open space to get to the truth. Materialism can only speak in its own territory, while there are many more areas that need to be entered by the method according to existence.

2) Reopening Metaphysics

There is two important discourse on the reopening of metaphysics, namely the existence of God and the human mind. ${ }^{53}$

First, The existence of God.The fallacy of materialism is about to be straightened by Nasr by overhaul the paradigm. Traditional cosmology offers an entrance that connects the natural science and metaphysics, a philosophy that speaks of the ultimate reality, the Absolute Reality in the structure of the cosmos. With the paradigm, the global community was about to be escorted to the knowledge of God as the center of reality have the truest form. ${ }^{54}$

Second, the human mind. In talking about the metaphysical dimension of human, traditional teachings revealed by Nasr was more

\footnotetext{
${ }^{53}$ Ach.Maimun, op. cit, p. 174

${ }^{54}$ SeyyedHossein Nasr, The Encounter of Man and Nature, p. 22
}

extensive. Traditional teachings have been talking about the soul deeper than the soul. In the spirit that is intellectually penetrating nature of metacosmic to achieve absolute reality. Therefore, it is a part of the intellectual property (the universal mind of the cosmos) as a higher level of reality in general in the theophanic ${ }^{55}$ process. $^{56}$

b) Combining Various Sources of Knowledge

With confidence in the ability of the scientific method-empirical paradigm of materialism, modern science finally does not recognize the truth from other sources that actually a lot of coloring of life, including religion and art. Then, they were herded into the subjective area that can't be measured by the lens of the scientific method, so that the truth is not recognized. Another implication of the hegemony of modern science is the establishment of a wide range of disciplines apart one with another. Various disciplines are mutually recognizing the truth in its own territory. In fact, modern science also

\footnotetext{
${ }^{55}$ Theophany is a symbolic showing of God (i.e. the Divine Attributes)

${ }^{56}$ SeyyedHossein Nasr, Knowledge and Sacred, p. 151
} 
Rif'at Husnul Ma'afi \& Muhammad Fiqih Cholidi | SeyyedHossein Nasr...

rejected knowledge that never existed before, thus giving birth to discontinuity of the history of science, as in medieval and Greece. ${ }^{57}$ So, melding into the character and mission of the New Story science related to religion and philosophy.

1) Removing Contrasting Aspect between Science and Religion

In the middle of the conflict between religion and science, Nasr is one of the leading figures were very adamantly opposed the disengagement of science and religion. He asserted that the biggest mistake of modern science was its separation from religion which he described as secular science. ${ }^{58}$ Therefore, the disengagement paradigms rooted from materialism, then Nasr tries to replace the paradigm with a new paradigm that is very religious.

Nasr's offering in the form of traditional cosmology is derived from religious teachings, but still traditional. Nasr's traditionalism rests on a fundamental view of religion as the teaching of eternal, transcendental, and universal.

\footnotetext{
${ }^{57}$ Ibid, p. 189

${ }^{58}$ SeyyedHossein Nasr, The Need for The Sacred Science, p. 3
}

Religion in the context of a variety of transhistorical religions captured by the intellectual acuity of Absolute Reality. ${ }^{59}$

Nasr's offering is not merely an attempt to rebuild the relationship between religion and science, but to make the teachings of the religion of nature become basic of science. Any science should be based on the doctrine that nature is sacred. Therefore, it is an Absolute Reality theophany through levels of reality. Science does not just dwell on the physical-material dimensions. This is because the nature of reality (Absolute Reality) is in the metacosmicdomain, ${ }^{60}$ In this case, Nasr does not want to build a dialogue between religion and science. Because Nasr put a higher religion and stick with traditional formulations without new interpretation. For Nasr, the truth of religion is the ultimate and eternal truth. So that science that should move in accordance with the lines set out religioncommonly.

2) Refer to Philosophy

\footnotetext{
${ }^{59}$ Ach.Maimun, op. cit, p. 198

${ }^{60}$ SeyyedHossein Nasr, Knowledge and the Sacred, p. 1
} 
It is closely linked to science and religious antagonism is divorce science and philosophy. Philosophy also speaks of the reality and is the source of knowledge. However, the philosophy has fundamental differences with science, especially in its domain of epistemology. Science relies on data obtained from sensory observations and experiments (empirical). Average philosophy rests on the ability of the mind which works on the basis of principles necessarily irrational, so speculative, as the principle of non-contradictory and analogies. Nevertheless, both are equally a source of human knowledge. Basically, science and philosophy is a device to see the universe and obtain the truth. ${ }^{61}$

For Nasr, philosophy is the eternal wisdom gained from optimizing the potential intellect inside. ${ }^{62}$ Eternal wisdom is the illumination of the Absolute Reality that manifests itself in various forms, such as art, religion, and science in the traditional sense. That eternal wisdom which is the ultimate truth.

\footnotetext{
${ }^{61}$ Harold H. Titus, et al., PersoalanpersoalanFilsafat, (Jakarta: PT. Crescent Star, 1984),p. 280-286

${ }^{62}$ SeyyedHossein Nasr, Knowledge and the Sacred, p. 70-71
}

This is evident from the teachings of the traditional philosopher who formulated the intellectual acumen of his experience to use, so they can find the truth that is in line with the teachings of religion in the traditional sense. Nasr also calls philosophy in this sense with the traditional metaphysics (traditional metaphysics). ${ }^{63}$

As the basic idea is to shift the old paradigm (modern science) with a new paradigm, Nasr was about to bring his philosophy as a paradigm. In the context of natural science, cosmology is a special branch that speaks of a philosophical nature. The idea of cosmology is very thick colored by traditional religious teachings and philosophy. Therefore, cosmology is a further explanation of the philosophical teachings of religion itself. Thus, it is expected cosmology (natural philosophy) a bridge and philosophical interpretation of religious teachings that should coloring science. Therefore, cosmology should be the paradigm of science, so those religious teachings

\footnotetext{
${ }^{63}$ Ibid, p. 103
} 
Rif'at Husnul Ma'afi \& Muhammad Fiqih Cholidi | SeyyedHossein Nasr...

can be accepted and became the basis of science in general. ${ }^{64}$

c) Light in Explanation of Reality

Another issue that is fundamental in modern science is the lack of brightness in the explanation of reality. In this case, the brightness which is questioned is in terms of a clear and distinct statement, without there are things that are still mysterious. Of course, not all theories in modern science. He was just about the major problems of reality which can't be explained by either because of the shackles of materialism paradigm. Thus, it can be said of materialism are not able to understand the material completely, ${ }^{65}$ so the explanation of nonmaterial reality still dark because of the limitations of materialism. ${ }^{66}$

Two important scientific issues are the mind (mind) and beauty (beauty), can be seen as an illustration of how modern science appeared with a dark face and was about to refined modern science with brightness.

1) Mind World

Various explanations of the world Nasr have explained get more

\footnotetext{
${ }^{64}$ Ach.Maimun, op. cit, p. 209

${ }^{65}$ Ach.Maimun, op. cit, p. 236

${ }^{66}$ Ibid, p. 238
}

closely related to metaphysics. $\mathrm{He}$ strongly emphasizes the inner dimension of man. In fact, he asserts the traditional teachings of man which consists of a body (hyle/corpus/ jism), spirit (psych/anima/nafs), and spirit (pneuma/spirit/soul) ${ }^{67}$ However, these explanations are put by Nasr in the context of human abilities reach the ultimate truth in nature metacosmic that can only be done by an intellectual in spirit. Other potential being only able to reach the outskirts of the truth that areaccidental. ${ }^{68}$

The significance of the Religion Nasr bring the idea is about the mind and spirit is more visible on therapeutic function for modern human alienation and spiritual crisis ${ }^{69}$ Being, in the domain of science, the idea is more a function to challenge scientists to uncover the deeper human dimension to enter the world of spirits. Because, so far, the achievements of human thought was still in the domain of thought that is also called the soul.

\footnotetext{
${ }^{67}$ SeyyedHossein Nasr, Knowledge and the Sacred, p. 172

${ }^{68}$ SeyyedHossein Nasr, Islam and The Plight of Modern Man, (Chicago: ABC International Group, 2001), p. 7

${ }^{69}$ Ach.Maimun, op. cit, p. 241
} 
2) Beautiful Universe

Apparently, Nasr did not see beauty as an important issue, so it does not formulate an explanation to resolve issues that are still mysterious in modern science. While in the context of enlightenment, Nasr felt more important to bring the quality of holy (sacred quality) is not caught reason scientists as the impact of traditionalism glasses. Nasr tried to give enlightenment to explain philosophical or cosmic reality in general. $^{70}$

All objects or the cosmos as a whole is a manifestation of the Absolute Reality (God). ${ }^{71} \mathrm{He}$ is not merely a material object or creature. By looking at it as a manifestation or theophany, Nasr gives another meaning to the creation of more clearly incomplete when scientists explain it, though they admit it. Creation in Nasr view embodied in the theophanic process through levels of reality, because God judged not to directly realize the universe in the form of material. ${ }^{72}$ As manifestations and theophany, all objects have the

\footnotetext{
${ }^{70}$ Ibid, p. 246

${ }^{71}$ SeyyedHossein Nasr, Knowledge and the Sacred, p. 214

${ }^{72}$ Ach.Maimun, op. cit, p. 246
}

elements of divinity as the light that has elements of the sun. The existence of the elements of what makes objects have sacred qualities. ${ }^{73}$

Awareness of the sacred quality is considered important by Nasr, because it will give birth to the friendly attitude to the environment and can lead people achieve goals of knowledge, namely selftranscendence, For him, knowing something is not to just know (science for science), master (knowledge is power), or the progress of mere life (science for the sake of human progress).${ }^{74}$ The idea was built by Nasr in order to rescue science from the secular character as found in modern science. The progress of science without awareness of the sacred quality of human will never usher in the Absolute Reality. And, the effort will be realized using intellectual tools in the spiritual nature of man, not just the senses or reason. ${ }^{75}$

\section{CONCLUSION}

From this thesis, the research concludes the points below:first, Islam on SeyyedHossein Nasr is not

\footnotetext{
${ }^{73}$ Ibid, p. 247

${ }^{74}$ SeyyedHossein Nasr, The Need for a Sacred Science, p. 98

${ }^{75}$ Ach.Maimun, op. cit, p. 247
} 
Rif'at Husnul Ma'afi \& Muhammad Fiqih Cholidi | SeyyedHossein Nasr...

just a religion. But it's a total way of life. Islam views human as a servant of God and God's representatives on earth. So that, Islam avoids human to act past God.

Science on SeyyedHossein Nasr is ever-changing knowledge of the physical world based on rationality and empiricism. He divides this science into two divisions, modern science, and Islamic science. Modern science develops against Islamic science which developed by Muslims and always relate closely to the principles of Islamic revelation and the spirit of Quran. His science known as sacred science or Scientia Sacra which is bound to be connected to revelation and metaphysical doctrine in whose bosom alone it becomes meaningful and efficacious. This Scientia Sacra can be used an alternative when modern science leads to secular science.

Nasr's model to integrate Islam and science isto transform the paradigm of modern science into the paradigm of his science by eliminating theroot problems of modern science and bringing in three new paradigms of his science characters: vastness, unity, and light.
The root problems of modern which cause new conflict between Islam and science are narrow, fragmented, and dark.The narrow character in modern science appears from it indwelling on material reality and not expanding the horizons of the possibility of another truth. Fragmented character due to modern science is not able to connect a variety of specialties and subspecial from diverse disciplines. Dark character is because modern sciences are not able to give a satisfactory explanation on several important issues, such as the beauty of the world of thoughts and dimension of cosmic reality.

To realize his integration model, he based his model on cosmological doctrine. Because he assumes that cosmological doctrine has main characters, there are collecting all knowledge that is fragmented into a universal and integral unity of the whole of science (inflict unity character), disclosing the nature and formulating it systematically (inflict light character), and remodeling modern science made barriers (inflict vast character). This cosmological doctrine also encourages to his science which 
Jurnal Yaqzhan : Analisis Filsafat, Agama dan Kemanusiaan|

Vol 5, No 1, Juni 2019

known as Scientia

SacrabecauseScientia Sacra is the basic of traditional knowledge about the cosmos.

\section{REFERENCES}

Augros, R. M., and George N. S. (1984). The New Story of Science: Mind and The Universe. Chicago: Gateway Editions.

Basya, A. F. (2004). Sumbangan Keilmuwan Islam Pada Dunia. Jakarta Timur: AlKautsar.

Guessoum,N. (2011). Islam's Quantum Question Reconciling Muslim Tradition and Modern Science. London: I.B. Tauris.

Hahn, L. E. (2001). The Philosophy of Seyyed Hossein Nasr. Chicago: Open Court Publishing Company.

John F. H.(1995). Science and Religion from Conflict to Conversation. New York: Paulist Press.

Maimun, A. (2015). Seyyed Hossein Nasr, Pergulatan Sains dan Spiritualitas Menuju Paradigma Kosmologi Alternatif. Yogyakarta: IRCiSoD.

Nasr, S. H.(1968). The Encounter of Man and Nature, the Spiritual Crisis of Modern Man. London: Allen \&Unwin.

(1984). The Role of The Traditional Sciences in The Encounter of Religion and Science Oriental Perspective. Journal Religious 